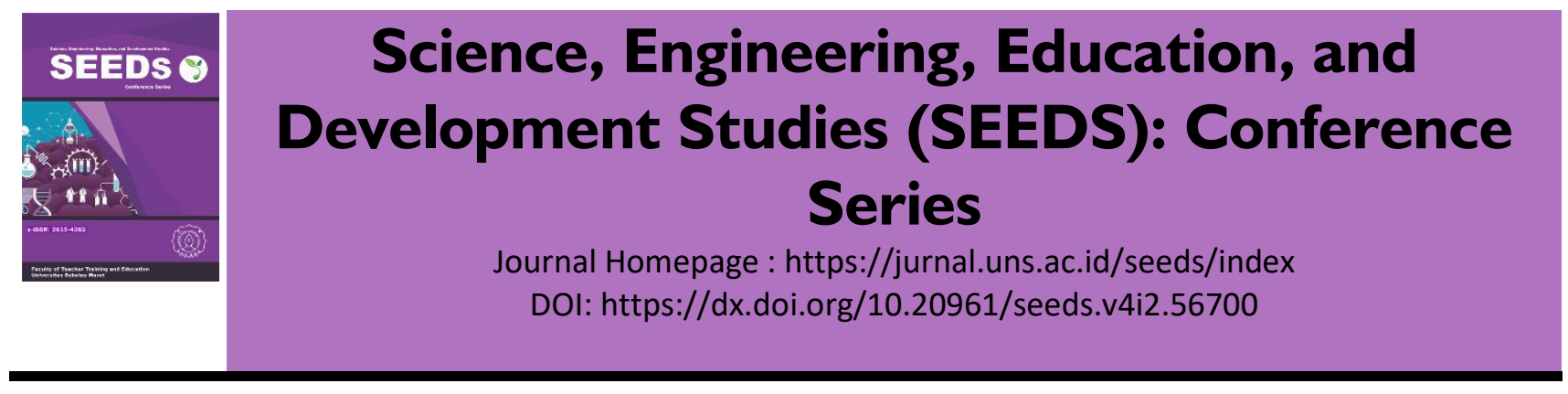

\title{
PENGARUH INTERNET BAGI SISWA-SISWI SMA NEGERI 3 PADANG
}

Nora Vitria

SMA Negeri 3 Padang

vitrianora@gmail.com

\section{Article Info :}

Available online $26 / 11 / 2021$

\section{Keywords:}

Internet

Pendidikan

Kasus

Sekolah

Peserta didik

\begin{abstract}
Pada zaman modern ini, internet sudah menjadi hal yang wajar, bahkan wajib. Apalagi di kalangan pendidikan. Internet sudah menjadi dunianya teknologi. Dimana bisa dipermudah dengan teknologi. Internet sebagai sumber informasi, banyak memberikan kemudahan. Apapun yang kita butuhkan bisa kita dapatkan melalui Internet. Akan tetapi, semakin berkembangnya Internet, ada dampak positif dan negatif yang terlihat saat ini. Apalagi yang berhubungan dengan pendidikan. Banyak pelajar yang mendapatkan ilmu dengan bantuan internet. Bahkan tugas-tugas sekolah sekalipun kini terasa lebih mudah dengan mencarinya di internet. namun tidak sedikit yang menyalahgunakan penggunaan internet itu. Tidak sedikit remaja yang malas belajar karena hampir semua waktunya untuk keperluan hura-hura melalui internet. Lebih-lebih remaja atau pelajar yang tanpa malu atau takut membuka situs-situs porno.Maka dari itu diperlukan dukungan dari lingkungan keluarga, lingkungan pendidikan, maupun lingkungan masyarakat untuk melakukan proteksi tersebut.
\end{abstract}




\section{PENDAHULUAN}

Teknologi selalu berkembang dan mengalami kemajuan sehingga semakin memudahkan manusia untuk beraktivitas, salah satu contoh kemajuan teknologi yang paling terlihat yaitu berkembangnya internet. Munculnya internet ini mempengaruhi berbagai aspek kehidupan manusia, termasuk dalam bidang pendidikan. Masuknya internet dalam bidang pendidikan tentunya juga akan membawa dampak bagi para pelajar. Dampak tersebut dapat berupa dampak positif ataupun negatif.

Seiring perkembangan dan kemajuan teknologi, kini mulai muncul media atau sarana-sarana baru di bidang pendidikan, yang diharapkan dapat mempermudah guru dan siswa untuk mengakses informasi yang mereka butuhkan. Dengan adanya perkembangan teknologi terutama internet, pelajar dapat mengakses materi di manapun mereka berada. Namun tanpa disadari adanya berbagai kemudahan ini disalah gunakan oleh oknum-oknum tertentu, yang justru dapat merusak moral dan mental pelajar sebagai generasi penerus.

Dari uraian di atas penulis mengambil judul "Pengaruh internet bagi siswa-siswi sma negeri 3 padang". Karena, dianggap menarik dan perlu di perhatikan oleh semua pihak terutama bagi mereka yang peduli terhadap perkembangan terknologi dan dunia pendidikan.

Adapun tujuannya adalah untuk mengetahui pengaruh internet terhadap minat belajar siswa, mengetahui perkembangan internet di kalangan pelajar, mengetahui manfaat dari adanya internet, mengetahui dampak positif dan negatif dari penggunaan internet di kalangan pelajar dan menginformasikan bagaimana cara menanggulangi dampak negatif dari penggunaan internet terhadap minat belajar siswa

Diharapkan dapat bermanfaat bagi pelajar untuk mengetahui dampak penggunaan internet dalam keseharian pelajar, serta cara menyikapi perkembangan internet agar tidak menurunkan minat belajar para pelajar dan bagi guru yaitu untuk mengetahui pengaruh internet terhadap minat belajar siswa, dan dapat digunakan sebagai acuan dalam pembelajaran yang berkaitan dengan internet.

\section{PEMBAHASAN}

\section{Pengertian Internet}

Internet merupakan kepanjangan dari interconnected networking. Istilah INTERNET berasal dari bahasa Latin inter, yang berarti "antara". Internet adalah sebuah dunia maya jaringan komputer (interkoneksi) yang terbentuk dari miliaran komputer di dunia. Internet merupakan hubungan antar berbagai jenis komputer dan jaringan di dunia yang berbeda sistem operasi maupun aplikasinya di mana hubungan tersebut memanfaatkan kemajuan media komunikasi (telepon dan satelit) yang menggunakan protokol standar dalam berkomunikasi. Internet memungkinkan kita untuk menghilangkan hambatan jarak dan waktu dalam mendapatkan informasi. Internet merupakan sebuah jaringan komunikasi dan informasi global.

Internet merupakan sistem global jaringan komputer yang berhubungan menggunakan standar Internet Protocol Suite (TCP / IP) untuk melayani miliaran pengguna di seluruh dunia. Ini adalah jaringan dari jaringan yang terdiri dari jutaan jaringan pribadi, umum, akademik, bisnis, dan jaringan pemerintah, dari lokal ke lingkup global, yang dihubungkan oleh sebuah kode array yang luas dari teknologi jaringan elektronik, nirkabel dan optik. Internet juga dapat didefinisikan sebagai interkoneksi seluruh dunia komputer dan jaringan komputer yang memfasilitasi sharing atau pertukaran informasi di antara pengguna.

Menjelaskan secara detail definisi internet memang sangat luas dan bisa mencangkup berbagai elemen penting, namun pada jaman sekarang ini untuk mempermudah penjelasan mengenai internet akan diberikan pemahaman awal dari komputer dan jaringan komputer yang berujung dengan lebih mudah untuk memahami internet.

Diawali Komputer yang merupakan sekumpulan alat elektronik yang dibuat sedemikian rupa sehingga bisa saling bekerja sama dengan baik mampu menerima data, mengolah data dan memberikan informasi dalam kontrol program. Lalu Jaringan komputer merupakan sistem terhubung atas komputer dan perangkat jaringan bekerjasama dalam satu tujuan untuk bisa berkomunikasi, akses informasi dan juga berbagi sumber daya. Nah, internet merupakan Jaringan komputer yang ruang lingkupnya global dunia atau dengan kata lain sistem jaringan komputer diseluruh penjuru dunia yang terhubung untuk tujuan seperti yang telah disebutkan yaitu komunikasi, akses informasi, berbagi sumber daya atau data. 


\section{Dampak Yang Ditimbulkan Internet \\ 1. Dampak Positif}

Internet sangat memberikan pengaruh positif bagi pelajar. Banyak pelajar yang mendapatkan ilmu dengan bantuan internet. Bahkan tugas-tugas sekolah sekalipun kini terasa lebih mudah dengan mencarinya di internet. Kalau dulu, orang harus membuka berbagai jenis buku dan koran untuk mencari tahu tentang suatu info, atau dengan menyimak radio dan televisi. Tapi kini, cukup dengan bantuan internet, semua info seakan membanjir.

Banyak pelajar yang sudah fasih dengan manfaat dan kegunaan situs-situs tertentu. Cukup dengan berkunjung ke wikipedia, misalnya, sesuatu masalah telah terselesaikan. Mereka juga dengan mudahnya googling untuk mencari tugas dari sekolah. Pelajar juga dapat menggunakan internet untuk membuka wawasan dan memperluas pergaulan mereka. Mereka dapat berteman dengan siapa saja dari mana saja. Pelajar pun dapat berlatih kemampuan bahasa asing yang mereka miliki dari teman-teman baru yang didapatnya dari internet.

Berbagai manfaat internet bagi siswa antara lain yaitu :

a. Memperluan wawasan dan ilmu pengetahuan,

b. Sebagai sumber tambahan pelajaran yang belum di mengerti di sekolah,

c. Membuat pelajar terbiasa dengan teknologi komputer dan informasi,

d. Menggunakan teknologi "teleconference" (konferensi interaktif secara on line dari jarak jauh),

e. karena dapat menghemat waktu,

f. tenaga pengajar,

g. kapasitas ruang belajar serta tidak mengenal letak geografis,

h. Surat menyurat (e-mail),

i. fasilitas ini sudah sering kali kita dengar karena dengan fasilitas ini tidak hanya untuk saling mengirim pesan yang pnjang tapi juga dapat digunakan untuk mengirim tugas dalam proses belajar,

j. Sebagai sarana komunikasi.

\section{Dampak Negatif}

Banyak manfaat yang mereka peroleh dari internet, terutama dalam proses komunikasi dan penggalian informasi, namun tidak sedikit yang menyalahgunakan penggunaan internet itu. Tidak sedikit remaja yang malas belajar karena hampir semua waktunya untuk keperluan hura-hura melalui internet. Lebih-lebih remaja atau pelajar yang tanpa malu atau takut membuka situs-situs porno.

Selain itu mereka juga terpengaruh oleh omongan-omongan para orang dewasa. Semua hal itu berdampak buruk bagi diri mereka sendiri maupun orang lain yang berada di dekat mereka. Mereka yang sekilas saja menyaksikan hal-hal porno akan terus menerus menyaksikannya karena mereka ketagihan. Tak lama kemudian sifat mereka akan berubah lebih buruk dan mereka semua akan terlibat dalam pergaulan bebas.

Adapun hal negatif yang ditimbulkan internet, antara lain :

a. Kejahatan penculikan terhadap remaja melaui jejaring sosial di dunia maya (internet),

b. Penipuan dalam jual beli online, Membuat remaja menjadi malas, karena waktu untuk bekerja membantu orang tua atau belajar tersita untuk berinternet, sehingga tugas-tugas sekolah sering terlantar, Para remaja menjadi terlalu bergantung pada internet

c. dalam mengerjakan tugas-tugas sekolah. Padahal tugas sekolah yang seharusnya dibuat sendiri, sering dikerjakan dengan copy paste

d. dari suatu alamat wap atau blog.Pikiran para remaja teracuni oleh sesuatu yang dapat merusak moral seperti film, gambar, foto, baca yang bersifat pornografi.

e. Sosialisasi remaja dalam masyarakat berkurang, karena para remaja menjadi lebih suka dan nyaman bersosialisasi dalam dunia maya.

f. Mereka jarang keluar rumah, mereka lebih suka menatap komputer atau laptopnya untuk berinternet hingga lupa waktu.

Jadi internet menimbulkan mafaat yang tiada batas bagi penggunanya, meskipun dalam kenyataan masih terdapat penyalahgunaan internet yang dapat membawa pengaruh kurang baik bagi mereka.

Solusi untuk mengatasi dampak negatif internet adalah peran orangtua. Peran orang tua sangatlah penting dalam meminimalisir dampak merugikan dari internet. Orangtua diharapkan berperan dalam mengawasi dan mengingatkan para remaja agar tidak melalaikan tugas utama mereka, yaitu belajar. Sehingga tugas perkembangan yang harus mereka peroleh selama masa remaja dapat tercapai dan menjadi bekal dalam menyongsong masa depan. Yang tidak kalah pentingnya adalah faktor dari dalam diri sendiri, karena 
keimanan dari dalam dirilah yang dapat membentengi diri dari semua pengaruh atau dampak negatif suatu apapun.

\section{KESIMPULAN}

Berdasarkan penjelasan di atas, dapat disimpulkan bahwa pengaruh Internet sangat besar pada kehidupan manusia. Terutama dalam aktifitas pendidikan. Berhasil tidaknya suatu pendidikan salah satunya tergantung pada sumber daya manusianya. Jika sumber daya manusianya tidak bisa memanfaatkan perkembangan teknologi yang ada dengan baik, maka imbasnya juga pada wajah pendidikannya. Awal munculnya internet, diharapkan memiliki banyak manfaat bagi manusia yang sangat berguna untuk komunikasi dan penyebaran informasi secara global. Namun sekarang yang terjadi, dampak buruk internet semakin banyak terlihat. Contohnya: video porno dapat diakses kapan saja, menariknya tampilan program-program di internet membuat orang lupa waktu, apalagi kalau sudah facebook-an, membuat produktifitas menurun. Oleh karena itu, sepatutnyalah kita dapat menggunakan internet dengan bijaksana. Sehingga dibutuhkan kendali diri dan juga kesadaran individu, terutama kalangan pendidikan dalam memanfaatkan pesatnya perkembangan Internet saat ini

\section{DAFTAR PUSTAKA}

A, Abraham. (2010). Tersesat di Dunia Maya. Surabaya: PT Java Pustaka.

Anonim. (2005). "Melindungi Anak Anda Saat Berinternet”. Yogyakarta: ANDI. Semarang: Wahan Komputer. 